\title{
Effect of Transverse Abdominis Plane Block on Chronic Post-Operative Pain-A Review
}

\author{
Darwin Lamichhane ${ }^{1}$, Xuelin Yang2 ${ }^{2}$ Zhengliang $\mathbf{M a}^{1,2^{*}}$ \\ ${ }^{1}$ Medical School of Southeast University, Nanjing, China \\ ${ }^{2}$ Department of Anesthesiology, Affiliated Drum Tower Hospital, Medical School of Nanjing University, Nanjing, China \\ Email: *mazhengliang1964@nju.edu.cn
}

How to cite this paper: Lamichhane, D. Yang, X.L. and Ma, Z.L. (2017) Effect of Transverse Abdominis Plane Block on Chronic Post-Operative Pain-A Review. Open Journal of Anesthesiology, 7, 23-34. https://doi.org/10.4236/ojanes.2017.72003

Received: January 18, 2017

Accepted: February 24, 2017

Published: February 27, 2017

Copyright (c) 2017 by authors and Scientific Research Publishing Inc. This work is licensed under the Creative Commons Attribution International License (CC BY 4.0).

http://creativecommons.org/licenses/by/4.0/

\section{cC (i) Open Access}

\begin{abstract}
Chronic post-operative pain is a recognized adverse consequence of surgery; managing and preventing it are always a better choice. Proper choice of Anesthetic technique, use of combined anesthesia and pre-emptive analgesia may prevent and decrease the incidence of chronic post-operative pain. Transverse abdominis plane block (TAP Block) is a regional anesthesia technique following abdominal surgeries which involve injection of a large amount of local anesthetics in TAP, an anatomical space between the internal oblique and transverse abdominis muscle. The aim of this review is to show the effect and uses of TAP block as a combined anesthesia and multimodal analgesia in preventing chronic post-operative pain.
\end{abstract}

\section{Keywords}

Chronic Post-Operative Pain, Transverse Abdominis Plane Block, Regional Anesthesia, Multimodal Analgesia

\section{Introduction}

Chronic post-operative pain (CPOP) is the most common type of chronic pain in patients attending pain clinic. A survey done about on 5000 patients found that $34.2 \%$ of patients visiting clinic have degenerative diseases and the second largest $22.5 \%$ of patients have chronic pain following the surgical procedure [1]. International Association for the study of pain (IASP) defines chronic pain as pain without apparent biological value that has persisted beyond the normal tissue; healing time is usually considered 3 months, however when it comes to CPOP, the working definition as mentioned in Table 1 written by Marcae and Davies, which is adopted and still frequently used [2]. Pain persists in most of the patients after thoracotomy, amputation, or breast surgery and even for lower abdominal surgeries 
Table 1. CPOP definition by Marcae and Davies [2].

1) Pain developing after surgical procedures.

2) Pain of at least two months of duration.

3) Causes such as malignancy or chronic infection should be excluded.

4) Pain continuing form a preexisting pain also must be excluded.

such as hernia and cesarean section. Surgeries between 2005-2006 done in UK show the highest of $50 \%-85 \%$ of chronic pain's patients with amputation and $5 \%$ - 35\% of incidence of chronic pain in hernia [3]. Mild post-operative chronic pain can significantly impact function and quality of life, whereas severe chronic pain is devastating in nature [4].

There are several risk factors which result in Chronic postoperative pain including preoperative, intraoperative and postoperative [1]. In case of abdominal surgeries, pain is due to incision in abdominal or visceral wall. Although the conventional method of anesthesia is effective, the post-operative risk of nausea, vomiting, opioids effects, urinary retention is usually inevitable. Several studies done say transverse abdominis plane block (TAPB) provides a good intraoperative and acute pain relief which also results in decrease in use of opioids resulting less opioids related complications, compared with anesthetic techniques like intravenous and spinal/epidural anesthesia with less compli-cations [5] [6] [7] [8] [9]. However, there has been less research on the relationship between CPOP and TAPB. Therefore, this review intends to establish the relationship between CPOP and TAPB and to show the usages of TAPB as multimodal anesthesia and pre-emptive analgesia.

\section{Mechanism of CPOP}

The actual mechanism of chronic pain after surgery is still not yet understood very clearly. It may be in part a failure of the nervous system to return to its initial settings before the injury [10]. Even in a single case of surgery different mechanism might be involved [11]. Usually chronic pain has their origins in an episode of acute pain which is particularly true of chronic pain after surgery. Acute pain due to surgical injury or incision initiates series of neurochemical reactions at the site of injury and also initiates a cascade of changes leading to sensitization in CNS. The occurrence of this hyperalgesic state may be advantageous and lead to less using of the injured part gradually allowing healing [10].

Initially it was believed that persistent post-surgical pain primarily is neuropathic in nature, but nowadays it is thought ongoing nociception might as well be playing role in this condition and blocking nociception during any part during the perioperative period may help prevent the occurrence of persistent pain after surgery [12] [13]. There is the neuroplasticity process also known as the physical remodeling of neuronal cytoarchitecture; a complex and in constant change in membrane excitability, reducing inhibitory mechanisms and increasing the excitatory synaptic efficacy. It occurs shortly after persistent acute pain which leads to the transition from acute pain into a state of chronic pain [14] [15]. It is said the 
process of neuroplasticity starts with the incision which causes surgical stimulation, which is maintained throughout the postoperative inflammatory process and ends only with the surgical healing [16]. Neuroplasticity are of two types, 1) peripheral, 2) central. Due to the activation on intracellular cascades with lower threshold, the injured tissues or inflammatory mediator cells releases inflammatory mediators which causes peripheral neuroplasticity, responsible for local hyper-excitability of high threshold peripheral nociceptive terminations. There may also be pain perception with a weaker stimulation. Where as in central neuroplasticity there is a synaptic change of spinal cord with the amplification of pain signal [12]. By the stimulation of peripheral nociceptive, intracellular kinases pathway is activated at the spinal cord dorsal horn changing ionic channels flow and the density of receptors and neurotransmitters. Post-synaptic hyper-excitability occurs due to central sensitization (CS) which increases the activity and density of AMPA and NMDA receptors. The increase of glutamatergic synapses in the spinal cord dorsal horn reinforces nociceptive stimulation transmission and recruits non nociceptive stimulation to the pain pathway. Due to activation of Nitric oxide (NO) and Kinase-C protein increase in the excitability of nociceptive neurons occurs [14]. NO induces sensitization of nociceptors. It increases the prostaglandin E2 release inhibiting the action of endogen ant-nociceptive substance on peripheral receptors acting directly on nociceptors. By the activation of NMDA receptor with subsequent production of NO, central sensitization is partially mediated [17]. After the induction of CS, there is an increase in responsiveness of neurons and even those which normally have ineffective synapse for stimulations, inoculate and activate neuronal pain transmission [12].

Whole process of Central Sensitization is considered to be very important factor for the development of persistent pain; hence the pharmacological interventions, good perioperative pain control and surgical techniques can be considered for minimize the central sensitization [18].

\section{Regional Anesthesia and Analgesic Consideration Affecting CPOP}

Local anaesthetics are used in regional anesthetic technique to block the conduction of impulses along nerves. It may possibly prevent the barrage of nociceptive inputs into the dorsal horn preventing central sensitization by minimizing the transmission of signals to or within the spinal cord. Peripheral nerve blocks and would infiltrations interrupt impulses in peripheral nerves whereas Subarachanoid block and edpiural block techniques act on the nerve roots [1]. A Cochrane review done among 23 RCTs and data pooled from 250 patients in three trials, found that epidural anesthesia for thoracotomy to be beneficial in reducing the risk of chronic pain at 6 months [4]. In case of limb amputation, nerve injury is unavoidable. It is one of the high risk factor associated with CPOP, however, perioperative epidural analgesia reduces the incidence of severe phantom limb pain [19]. Spinal anaesthesia has also been shown to be beneficial relative to general anaesthesia in reducing the risk of chronic pain after caesarean section [20]. The above studies gives some evidence for the benefit of regional anesthetic techniques in some of 
the surgeries in reducing the chronic pain after surgery but still yet further studies has to be carried out for different surgical approach.

\section{Transverse Abdominis Plane Block}

Anatomically, spinal nerves arising from T7 to T11 run along the neurovascular plane lying in the anterior abdominal wall between internal oblique and the transverse abdominis musclecalled the Transverse Abdominis Plane (TAP). The L1 (ilioinguinal and iliohypogastric) and T12 (subcostal nerve) also travels through the same plane [21]. Local anesthetics deposited in this area will target the nerves running in TAP, blocking the pain signals below and upper umbilicus [21]. The above nerve segments while travelling the TAP, branches individually and communicate extensively with others. It was noted that nerve segments entered the TAP in an inferolateral distribution from the costal margin such that segments from T6 entered to the linea alba whereas segments from T9 entered near the anterior axillary line (Figure 1). Between the costal margin and the ileum, near the triangle of petit along the anterior axillary line, nerves running in the TAP originate strictly from T9-L1 [22]. Rafi [23] and McDonnell [24] were the first to describe this novel abdominal field block and described an anatomical landmark technique, and provided evidence of blockade to the mid/lower thoracic and upper lumbar spinal nerves as they travelled in the fascial plane between the transversus abdominis and internal oblique muscles. TAP Block under ultrasound guidance has become a regional block technique with wide indications, which can be used for postoperative analgesia in patients with less complications. Three common approaches Subcostal, midaxillary and ilioinguinal-iliohypogastric can be used for the TAPB and each respected approach is contingent on the type of the surgical procedure and location [25]. This method is similar to that of nerve block of groin and abdominal nerve but more extensive. Although more scholars believe that unilateral TAPB can block from T7-L1 of the anterior abdominal wall, muscles and peritoneum, still clinically some individuals seemed to have poor analgesic effect where the block couldn't meet the requirement [26].

\section{Clinical Studies on TAP Block and Chronic Post-Operative Pain}

Poorly controlled perioperative pain and acute phase pain plays a significant role in the development and severity of chronic post-operative pain [27] [28]. TAPBlock as multimodal analgesia and as a part of combined anesthesia plays a good role in variety of abdominal surgery and improves the postoperative analgesic effects, enhances recovery [29] [30] [31] [32], and also prevents chronic post-operative pain in compared with spinal and general anesthesia [33]. Study characteristics and design are presented in Table 2.

\section{Discussion}

Chronic post-operative pain following inguinal herniorrhaphy accounts for $12 \%$ of the patients, effecting quality of life as well [39]. Topal et al. [33] in a retrospective 


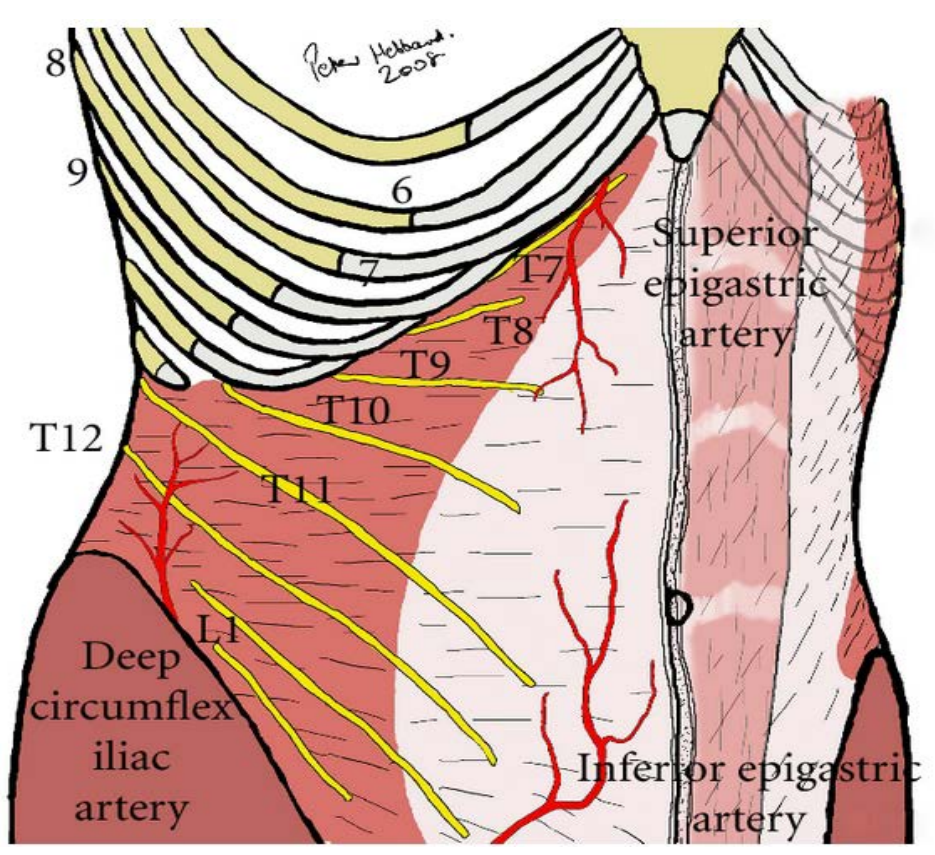

Figure 1. Distribution of nerves in the (TAP) transverse abdominis plane. Generously shared from the personal files of Prof. P. Hebbard.

Table 2. Comparative clinical studies.

\begin{tabular}{|c|c|c|c|c|c|c|c|}
\hline $\begin{array}{l}\text { Study (Prospective } \\
\text { Randomized } \\
\text { Control Trial) }\end{array}$ & Operation & $\begin{array}{c}\text { nTAP/ } \\
\text { nControl }\end{array}$ & TAP Block & Anesthetic & $\begin{array}{l}\text { Post-Op } \\
\text { Analgesia }\end{array}$ & $\begin{array}{l}\text { Effect on } \\
\text { Acute } \\
\text { Pain Score }\end{array}$ & $\begin{array}{l}\text { Effect on } \\
\text { CPOP }\end{array}$ \\
\hline $\begin{array}{c}\text { Topal } \\
\text { et al. }[33]\end{array}$ & Hernioplasty & $40 / 40 / 40$ & $\begin{array}{c}\text { Bilateral USG } \\
\text { Bupivacaine } 20 \mathrm{ml} \text { of } \\
0.25 \%\end{array}$ & $\begin{array}{l}\text { General Anesthesia and } \\
\text { Spinal (12.5 mg Bupivicane } \\
\text { and } 0.15 \mathrm{mg} \text { Morphine) }\end{array}$ & Tramadol & Reduced & Reduced \\
\hline $\begin{array}{l}\text { Aveline C } \\
\text { et al. }[34]\end{array}$ & $\begin{array}{l}\text { Open Inguinal } \\
\text { Hernia Repair }\end{array}$ & $134 / 139$ & $\begin{array}{c}\text { Bilateral USG } \\
\text { Levobupivacaine } \\
1.5 \mathrm{mg} / \mathrm{kg} \text { of } 0.15 \%\end{array}$ & $\begin{array}{l}\text { General Anesthesia } \\
\text { and/or INH Block }\end{array}$ & $\begin{array}{l}\text { Morphine, } \\
\text { Paracetamol, } \\
\text { Ketoprofen }\end{array}$ & Reduced & No Difference \\
\hline $\begin{array}{l}\text { Arora S } \\
\text { et al. [35] }\end{array}$ & $\begin{array}{c}\text { Laparoscopic } \\
\text { Inguinal Hernia } \\
\text { Repair }\end{array}$ & $35 / 36$ & $\begin{array}{c}\text { Bilateral USG } \\
\text { Ropivacaine } \\
15-20 \mathrm{ml} \text { of } 0.5 \%\end{array}$ & General Anesthesia & $\begin{array}{l}\text { Fentanyl PCA, } \\
\text { Paracetamol }\end{array}$ & Reduced & No Difference \\
\hline $\begin{array}{l}\text { Amr YM } \\
\text { et al. [36] }\end{array}$ & Hysterectomy & $23 / 23 / 22$ & $\begin{array}{l}\text { Bilateral Landmark } \\
\text { Bupivacaine } \\
20 \mathrm{ml} \text { of } 0.375 \%\end{array}$ & General Anesthesia & Morphine & Reduced & Reduced \\
\hline $\begin{array}{c}\text { McKeen DM et al. } \\
{[37]}\end{array}$ & $\begin{array}{l}\text { Cesarean } \\
\text { Delivery }\end{array}$ & $41 / 42$ & $\begin{array}{l}\text { Bilateral USG } \\
\text { Ropivacaine } \\
20 \mathrm{ml} \text { of } 0.25 \%\end{array}$ & General Anesthesia & $\begin{array}{l}\text { Naprozyn, } \\
\text { Acetaminophen, } \\
\text { Oxycodone }\end{array}$ & $\begin{array}{c}\text { No } \\
\text { Difference }\end{array}$ & $\begin{array}{c}\text { No } \\
\text { Difference }\end{array}$ \\
\hline $\begin{array}{c}\text { Chandon } \mathrm{M} \text { et al. } \\
{[38]}\end{array}$ & $\begin{array}{l}\text { Cesarean } \\
\text { Delivery }\end{array}$ & $36 / 29$ & $\begin{array}{c}\text { Bilateral USG } \\
\text { Lepobupivacaine } \\
20 \mathrm{ml} \text { of } 0.375 \%\end{array}$ & $\begin{array}{c}\text { Spinal Anesthesia } \\
\text { (Bupivacine + Sufentanil) }\end{array}$ & $\begin{array}{l}\text { Paracetamol, } \\
\text { Ketoprofen, } \\
\text { Nefopam, } \\
\text { Morphine }\end{array}$ & $\mathrm{n} / \mathrm{a}$ & $\mathrm{n} / \mathrm{a}$ \\
\hline
\end{tabular}

study; effect of Ultra sound guided TAPB. In hernioplasty on chronic pain, 3 groups were divided including 40 patients in each group with minimum of 6 months passed since the surgery done, Group T patients received TAP block with general anesthesia, Group S received spinal anesthesia and Group G received IV analgesia with general anesthesia. During early post operative pain evaluation no 
statistically significant difference was found among the groups $(\mathrm{p}>0.05)$. But slightly statistically significant difference was found when the Visual Analogue Score (VAS) of the patients with pain were compared $(\mathrm{p}=0.000)$. Whereas while comparing chronic pain, statistically significant difference was found among the groups in terms of chronic pain rates, $47.5 \%$ in Group G, 20.0\% in Group T and $40.0 \%$ in Group S, the p value was 0.030 . Development of chronic post operative pain was found lower in Group T compared with Group $G(p=0.000)$ and Group $S(p=0.003)$. However, no any statistically difference were found in VAS, frequency and nature of pain, sleep and daily activities among the patients with chronic pain $(p>0.05)$. It was concluded in the study that TAPB used as combined anesthesia along with general anesthesia can decrease the incidence of chronic post-operative pain. Yet the author recommended further prospective clinical trials due to retrospective nature of the study.

Another study conducted among inguinal hernia repair patients, comparison of TAPB guided by USG and ilioinguinal/iliohypogastric nerve block. $273 \mathrm{~Pa}-$ tients were randomly allocated into 2 groups. Both the group received general anesthesia after the nerve blocks. The study showed patient given TAPB had better pain management in immediate postoperative period but comparing the VAS of both groups at 3 and 6 months after surgery at rest and movement, no difference were noted between both the groups. TAP block was found having no any better impact on prevention of chronic post-operative pain in compared to the other method [34]. But the reason may be because both the method follows the similar principle and the nerves to be anesthetized during the TAPB (T7-L1) include both the iliohypogastric and ilioinguinal nerves. Therefore both the group may have the similar impact upon the chronic post-operative pain.

Recent study done by Shubhangi Arora [35] was done by allocating 71 patients randomly to see acute and persistent post-operative chronic pain for patients undergoing laparoscopic inguinal hernia repair using TAPB. Both the group received general anesthesia, whereas one group received bilateral USG TAPB after the induction. Result showed the patients who received TAP Block had reduced pain up to 24 hours after the surgery. As well, less pain complaint was noticed at Week 1 and 3 month in TAP Block group compared with the control group but statistically no difference was noted. It may be due to lesser number of the sample size thus further study was recommended.

Chronic pain after abdominal hysterectomy accounts for 5\% - 32\% [40]. Study done my Yasser Md [36] on effect of TAP block pre- and post-incisional on acute and chronic pain in patients undergoing hysterectomy, 75 patients were randomized to 3 groups where two groups received TAP block pre-incisional after general anesthesia and before the emergence from general anesthesia whereas one group just received sham block after the general anesthesia where just needle was inserted and no drugs was injected as control group. Post-operative analgesic requirement was significantly decreased in pre-incisional group than the other two groups and also the consumption of morphine was significantly reduced in the ward in the first 48 hours. VAS of pre-incisional TAPB group was significantly 
lower than the other two groups. It was also noted the incidence of chronic pain at three and six months was decreased significantly in the pre incisional group in compared with post incisional TAPB group and the control group ( $p=0.035$, 0.029 respectively). $17.4 \%$ patients in the control group and $13.6 \%$ in the other group were using NSAID as a mode of analgesia and pain control whereas non of the patients in pre-incisional TAPB group used. Hence it was concluded that TAP block as preemptive analgesia before the hysterectomy had better postoperative analgesia and significant reduction in the incidence of chronic postoperative pain.

Cesarean section is one of the common surgery with incidence of chronic post-operative pain which accounts for $18 \%$ of patients [41]. Dolores et al. [37] conducted a randomized controlled trial including 83 patients undergoing cesarean delivery under spinal anesthesia. After the surgery post operatively patients received $30 \mathrm{mg}$ of ketorolac, $4 \mathrm{mg}$ of ondansetron, acetaminophen $1 \mathrm{gm}$ and bilateral US guided TAP block. The TAP block was randomized into two groups of $(0.25 \% 20 \mathrm{ml}$ ropivacaine) and (0.9\% $20 \mathrm{ml}$ Normal Saline) as control group. The result concluded, TAP block failed to improve postoperative pain, reduction in opioids consumptions and chronic post-operative pain.

Similarly, Chandon M. et al. [38] conducted a RCT between US guided TAP block and Continuous wound infusion for post-operative analgesia. 80 patients were randomized and after the surgery under subarachnoid block, bilateral US guided TAP block of $20 \mathrm{ml}$ of $0.3755 \%$ levobupivicaine or a continuous would infusion via an elastometric pump delivering $5 \mathrm{ml} /$ hour of $250 \mathrm{mg}$ of levobupivacaine in $200 \mathrm{ml}$ of solution set. Intravenous morphine was optional if the pain score (Verbal response numerical scale) was 4 or higher. There was no significant difference between the two groups in the rates pain during rest or motion and in morphine consumption. Also there was no significant difference in incidence of chronic pain between the two groups.

In different abdominal surgeries, the effect of TAP Block has different effects on chronic post-operative pain. It may be due to the limited sample size of the patients, different surgical methods and different anatomy involved in different kind of surgery. As above studies mentioned, in the case of incisional hernia the effect of block seemed to be pronounced in reduction of chronic post-operative pain whereas in cesarean section there seemed to have no effect. Used as a preemptive analgesia in hysterectomy also showed a significant reduction in incidence of chronic pain. It can be used as a combined anesthesia with general anesthesia or spinal and also could be used as a multimodal analgesia and preemptive analgesia.

\section{Complications of TAP Block}

Since the development of ultrasound guided technique no organ injuries have been reported while the procedure [42] except one case of liver injury which was said due to the result of excessive depth of penetration due to failure to accurately image the entire needle during the procedure [43]. Farooq et al. [44] also reported 
a case of liver injury while using the Landmark based technique. There have also been reports of occurrence of intestinal hematoma as well [45]. Local anesthetic systemic toxicity may occur during any procedure of regional anesthesia if the large volume of local anesthetics enters the blood vessels. A case of local anesthetic poisoning in TAP block during Cesarean section was reported [46]. This complication can be avoided by careful aspiration during the procedure. Other complication includes such as intra-peritoneal injection, bowel hematoma, visceral damage and transient femoral nerve palsy [42]. There may be always the possibility of under-reported minor complications as well.

\section{Conclusion}

Effective management of chronic post-operative pain not only eases the discomfort caused by the pain but also increases the quality of life of the patients. As an anesthetist we need to think the preventive rather than the curative way for the chronic post-operative pain. As there is not any standard way for the treatment of the chronic post-operative pain, but as a preventive way, we can give the patient a better perioperative pain management by choosing the appropriate way of anesthetic procedure, actively dealing with the acute post-operative pain which may eventually help in reduction in the chronic post-operative pain. TAP block used as a multimodal analgesia and combined anesthesia may have a positive effect on reduction in incidence of chronic post-operative pain and can alsobe a good alternative for patients, highly sensitive to opioids. It also has a high margin of safety and is technically easy to perform, especially under guidance of ultrasound. Its uses in variety of abdominal procedures can be taken as a benefit for its usage. TAP block also can be used as a pre-emptive analgesia for the reduction of central sensitization which has an impact on chronic post-operative pain. The procedures' ability to reduce opioids consumption, improve reduction of acute pain eventually leading to decrease in chronic post-operative pain can lead a greater patient satisfaction. However, still further studies and clinical trials with larger sample sizes and different subjects need to be conducted in different kinds of surgeries.

\section{References}

[1] Reddi, D. and Curran, N. (2014) Chronic Pain after Surgery: Pathophysiology, Risk Factor and Prevention. Postgraduate Medical Journal, 90, 222-227. https://doi.org/10.1136/postgradmedj-2013-132215

[2] Macrae, W.A. and Davies, H.T.O. (1999) Chronic Postsurgical Pain. In: Crombie, I.K., Ed., Epidemiology of Pain, IASP Press, Deattle, 125-142.

[3] Macrae, W.A. (2008) Chronic Post-Surgical Pain: 10 Years on. BJA British Journal of Anaesthesia, 101, 77-86. https://doi.org/10.1093/bja/aen099

[4] Andrae, M.H. and Andrae, D.A. (2013) Regional Anesthesia to Prevent Chronic Pain after Surgery: A Cochrane Systematic Review and Meta-Anylasis. $B J A, 11,711$ 720. https://doi.org/10.1093/bja/aet213

[5] Findlay, J.M., Ashraf, S.Q. and Congahan, P. (2012) Transversus Abdominis Plane (TAP) Block-A Review. The Surgeon, 10, 361-367. 
https://doi.org/10.1016/j.surge.2012.07.005

[6] Gao, T., Zhang, J.J., Xi, F.C., Shi, J.L., Lu, Y., Tan, S.J., et al. (2016) Evaluation of Transversus Abdominis Plane (TAP) Block in Hernia Surgery: A Meta-Analysis. The Clinical Journal of Pain.

[7] Omur, D., Oguzalp, H., Kiraz, H.A., Ekin, S., Alan, C., Ersay, A.R., et al. (2016) The Analgesic Efficiacy of Ultrasound-Guided Transversus Abdominis Plane Block on Postoperative Pain and Morphine Consumption in Varicocelectomy. Saudi Medical Journal, 37, 648-655. https://doi.org/10.15537/smj.2016.6.14332

[8] Jakobsson, J., Wickerts, L., Forsberg, S. and Ledin, G. (2015) Transversus Abdominal Plane (TAP) Block for Postoperative Pain Management: A Review. F10000 Research, 4, 1359.

[9] Ghimire, A., Bhattarai, B., Prasad, J.N. and Shah, S.P. (2015) The Analgesic Effectiveness of Ipsilateral Transversus Abdominis Plane Block in Adult Patients Undergoing Appendectomy: A Prospective Randomized Controlled Trial. Kathmandu University Medical Journal, 13, 361-365.

[10] Neil, M.J. and Macrae, W.A. (2009) Post Surgical Pain-The Transition from Acute to Chronic Pain. British Journal of Pain, 3, 6-9. https://doi.org/10.1177/204946370900300203

[11] Vermelis, J.M., Wassen, M.M., Fiddelers, A.A., Nijhuis, J.G. and Marcus, M.A. (2010) Prevalence and Predictors of Chronic Pain after Labor and Delivery. Current Opinion in Anaesthesiology, 23, 295-299.

[12] Kehleth Jensen, T.S. and Woolf, C.J. (2006) Presistent Postsurgical Pain: Risk Factors and Prevention. Lancet, 367, 1618-1625.

https://doi.org/10.1016/S0140-6736(06)68700-X

[13] Katz, J., Clarke, H. and Seltzer, Z. (2011) Review Article: Preventive Analgesia: Quo vadimus? Anesthesia and Analgesia, 113, 1242-1253.

https://doi.org/10.1213/ANE.0b013e31822c9a59

[14] Latermoliere, A. and Woolf, C.J. (2009) Central Sensitization: A Generator of Pain Hypersensitivity by Central Neural Plasticity. Journal of Pain, 10, 895-926. https://doi.org/10.1016/j.jpain.2009.06.012

[15] Voscoloulous, C. and Lema, M. (2010) When Does Acute Pain Becomes Chronic? British Journal of Anaesthesia, 105, i69-i85. https://doi.org/10.1093/bja/aeq323

[16] Gerbershagen, H.J., Özgür, E., Dagtekin, O., Straub, K., Heidenreich, A., Sabatowski, R., et al. (2009) Pre-Operative Pain as a Risk Factor for Chronic Post-Surgical Pain Six Month Follow-Up after Radical Prostatectomy. European Journal of Pain, 13, 1054-1061. https://doi.org/10.1016/j.ejpain.2008.11.020

[17] Burke, S. and Shorten, G.D. (2009) When Pain after Surgery Doesn't Go Away. Biochemical Society Transactions, 37, 318-322. https://doi.org/10.1042/BST0370318

[18] Sandkuhler, J. (2009) Models and Mechanisms of Hyperalgesia and Allodynia. Physiological Reviews, 89, 707-758. https://doi.org/10.1152/physrev.00025.2008

[19] Macinytre, P.E., Schug, S.A., Scott, D.A., Visser, E.J. and Walker, S.M. (2010) Acute Pain Management: Scientific Evidence, APM: SE Working Group of the Australian and New Zealand College of Anaesthetists and Faculty of Pain Medicine. 3rd Edition, ANZCA \& FPM, Melbourne.

[20] Nikolajsen, L., Sørensen, H.C., Jensen, T.S. and Kehlet, H. (2004) Chronic Pain Following Caesarean Section. Acta Anaesthesiologica Scandinavica, 48, 111-116. https://doi.org/10.1111/j.1399-6576.2004.00271.x

[21] Webster, K. (2008) The Transversus Abdominis Plane (TAP) Block: Abdominal Plane Regional Anesthesia. Update in Anesthesia, 24, 25-30. 
[22] Rozen, W.M., Tran, T.M.N., Ashton, M.W., Barrington, M.J., Ivanusic, J.J. and Taylor, G.I. (2008) Refining the Course of the Thoracolumbar Nerves: A New Understanding of the Innervation of the Anterior Abdominal Wall. Clinical Anatomy, 21, 325-333. https://doi.org/10.1002/ca.20621

[23] Rafi, A.N. (2001) Abdominal Field Block: A New Approach via the Lumbar Triangle. Anaesthesia, 56, 1024-1026. https://doi.org/10.1046/j.1365-2044.2001.02279-40.x

[24] McDonnell, J.G., O’Donnell, B.D., Tuite, D., Farrell, T. and Power, C. (2004) The Regional Abdominal Field Infiltration Technique Computerised Tomographic and Anatomical Identification of a Novel Approach to the Transversus Abdominis Neuro-Vascular Fascial Plane. Anaesthesiology, 101, A899.

[25] Urigel, S. and Molter, J. (2014) Tranversus Abdominis Plane (TAP). AANA Journal, 82, 73-79.

[26] Grifths, J.D., Middle, J.V., Baron, F.A., Grant, S.J., Popham, P.A. and Royse, C.F. (2010) Transversus Abdominis Plane Block Does Not Provide Additional Benefit to Multimodal Analgesia in Gynecological Cancer Surgery. Anesthesia \& Analgesia, 111, 797-801. https://doi.org/10.1213/ANE.0b013e3181e53517

[27] Katz, J., Jackson, M., Kavanagh, B.P. and Sandler, A.N. (1996) Acute Pain after Thoracic Surgery Predicts Longterm Post-Thoracotomy Pain. Clinical Journal of Pain, 12, 50-55. https://doi.org/10.1097/00002508-199603000-00009

[28] Nikolajsen, L. and Mineal, C.E. (2009) Acute Post Operative Pain as Risk Factor for Chronic Pain after Surgery. European Journal of Pain Supplements, 3, 29-32. https://doi.org/10.1016/j.eujps.2009.07.011

[29] Johns, N., O’Neil, S., Ventham, N.T., Barron, F., Brady, R.R. and Daniel, T. (2012) Clinical Effectiveness of Transversus Abdominis Plane (TAP) Block in Abdominal Surgery: A Systematic Review and Meta-Analysis. Colorectal Disease, 14, e635-e642. https://doi.org/10.1111/j.1463-1318.2012.03104.x

[30] Carney, J., McDonnell, J.G., Ochana, A., Bhinder, R. and Laffey, J.G. (2008) The Transversus Abdominis Plane Block Provides Effective Postoperative Analgesia in Patients Undergoing Total Abdominal Hysterectomy. Anesthesia and Analgesia, 107, 2056-2060. https://doi.org/10.1213/ane.0b013e3181871313

[31] Fusco, P., Scimia, P., Paladini, G., Fiorenzi, M., Petrucci, E., Pozone, T., et al. (2015) Transversus Abdominis Plane Block for Analgesia after Cesarean Delivery. A Systematic Review. Miner Vaanestesiologica, 81, 195-204.

[32] McDonnel, J.G., O’Donnel, B., Curley, G., Heffernan, A., Power, C. and Laffey, J.G. (2007) The Analgesic Efficacy of Transversus Abdominis Plane Block after Abdominal Surgery: A Prospective Randomized Controlled Trial. Anesthesia \& Analgesia, 104, 193-197. https://doi.org/10.1213/01.ane.0000250223.49963.0f

[33] Ahmet, T., Mehmet, S., Alper, K. and Sema, T.U. (2015) The Effect of Transversus Abdominis Plane Block in Inguinal Hernioplasty on Chronic Pain. European Journal of General Medicine, 12, 291-297.

[34] Aveline, C., LeHetet, H., LeRoux, A., Vautier, P., Cognet, F., Vinet, E., et al. (2011) Comparison between Ultrasound Guided Transversus Abdominis Plane and Conventional Ilioinguinal/Iliohypogastric Nerve Blocks for Daycase Open Inguinal Hernia Repair. British Journal of Anaesthesia, 106, 380-386. https://doi.org/10.1093/bja/aeq363

[35] Arora, S., Chhabra, A., Subramaniam, R., Arora, M.K., Misra, M.C. and Bansal, V.K. (2016) Transversus Abdominis Plane Block for Laproscospic Inguinal Hernia Repair: A Randomized Trial. Journal of Clinical Anesthesia, 33, 357-364. https://doi.org/10.1016/j.jclinane.2016.04.047 
[36] Amr, Y.M. and Amin, S.M. (2011) Comparative Study between Effect of Pre-Versus Post-Incisional Transversus Abdominis Plane Block on Acute and Chronic PostAbdominal Hysterectomy Pain. Anesthesia: Essays and Researches, 5, 77-82. https://doi.org/10.4103/0259-1162.84199

[37] McKeen, D.M., George, R.B., Boyd, J.C., Allen, V.M. and Pink, A. (2014) Transversus Abdominis Plane Block Does Not Improve Early or late Pain Outcomes after Cesarean Delivery: A Randomized Controlled Trial. Canadian Journal of Anesthesia, 61, 631-640. https://doi.org/10.1007/s12630-014-0162-5

[38] Chandon, M., Bonnet, A., Burg, Y., Barnichon, C., Mesnards-Samaja, V., Sitbon, B., et al. (2014) Ultrasound-Guided Transversus Abdominis Plane Block versus Continuous Wound Infusion for Post-Caesarean Analgesia: A Randomized Trial. PLoS ONE, 9, e103971. https://doi.org/10.1371/journal.pone.0103971

[39] Aasvang, E. and Kehlet, H. (2005) Chronic Postoperative Pain: The Case of Inguinal Herniorhaphy. British Journal of Anaesthesia, 95, 69-76.

https://doi.org/10.1093/bja/aei019

[40] Brandsborg, B., Nikolajsen, L., Hansen, C., Kehlet, H. and Jensen, T.S. (2007) Risk Factors for Chronic Pain after Hysterectomy: A Nationwide Questionnaire and Database Study. Anesthesiology, 106, 1003-1012. https://doi.org/10.1097/01.anes.0000265161.39932.e8

[41] Kainu, J.P., Sarvela, E., Halmesmaki, E. and Korttila, K.T. (2010) Persistent Pain after Caesarean Section and Vaginal Birth: A Cohort Study. International Journal of Obstetric Anesthesia, 19, 4-9. https://doi.org/10.1016/j.ijoa.2009.03.013

[42] Karim, M. (2009) Transversus Abdominis Plane (TAP) Block. Journal of New York School of Regional Anesthesia, 12, 28-33.

[43] Lancaster, P. and Chadwick, M. (2010) Liver Trauma Secondary to UltrasoundGuided Transversus Abdominis Plane Block. British Journal of Anaesthesia, 104, 509-510. https://doi.org/10.1093/bja/aeq046

[44] Farooq, M. and Carey, M. (2008) A Case of Liver Trauma With a Blunt Regional Anesthesia Needle While Performing Transversus Abdominis Plane Block. Regiona Anesthesia and Pain Medicine, 33, 274-275. https://doi.org/10.1097/00115550-200805000-00016

[45] Frigon, C., Mai, R., Valois-Gomez, T. and Desparmet, J. (2006) Bowel Hematoma Following an Iliohypogastric Ilioinguinal Nerve Block. Pediatric Anesthesia, 16, 993-936. https://doi.org/10.1111/j.1460-9592.2006.01909.x

[46] Bollag, L., Richebe, P., Siaulys, M., Ortner, C.M., Gofeld, M. and Landau, R. (2012) Effect of Transversus Abdominis Plane Block with and without Clonidine on PostCesarean Delivery Wound Hyperalgesia and Pain. Regional Anesthesia and Pain Medicine, 37, 508-514. https://doi.org/10.1097/AAP.0b013e318259ce35 


\section{Abbreviation}

Chronic Post-Operative Pain-CPOP

Transverse Abdominis Plane Block-TAPB

International Association for the Study of Pain-IASP

Central Sensitization-CS

Nitric Oxide-NO

Randomized Control Trials-RCT

Visual Analogue Scale-VAS

Ultra Sound Guided-USG

Submit or recommend next manuscript to SCIRP and we will provide best service for you:

Accepting pre-submission inquiries through Email, Facebook, LinkedIn, Twitter, etc. A wide selection of journals (inclusive of 9 subjects, more than 200 journals) Providing 24-hour high-quality service User-friendly online submission system Fair and swift peer-review system Efficient typesetting and proofreading procedure Display of the result of downloads and visits, as well as the number of cited articles Maximum dissemination of your research work

Submit your manuscript at: http://papersubmission.scirp.org/ Or contact ojanes@scirp.org 